stych walorów naukowych odbytej podróży należy podkreślić również jej korzyści interpersonalne. Czas spędzony w gronie koleżanek i kolegów ze studiów, spotkania przy stole eucharystycznym i wspólne posiłki sprzyjały wzajemnemu poznaniu się i integracji.

W imieniu doktorantów chciałybyśmy złożyć serdeczne podziękowania ks. prof. Marcinowi Wysockiemu i ks. dr. Marcinowi Nabożnemu za zorganizowanie tego wyjazdu, mając jednocześnie nadzieję, że podobne podróże staną się coroczną praktyką naszego Instytutu. Bez wątpienia był to znakomity czas spędzony w miłej atmosferze, a przede wszystkim niepowtarzalna okazja zapoznania się z funkcjonowaniem wybranych instytucji kościelnych oraz pogłębienia wiedzy teoretycznej nabytej w trakcie wykładów z historii Kościoła, zwłaszcza archeologii chrześcijańskiej. Pobyt w Rzymie stał się dla wszystkich inspiracją do dalszych studiów nad historią chrześcijaństwa.

Katsiaryna Laurynenka, Joanna Pyszna, Lublin - KUL

\title{
LIV Międzynarodowy Kongres Studiów nad Średniowieczem oraz Konferencja Studiów Cysterskich i Monastycznych, Kalamazoo, MI, USA, 9-12 maja 2019
}

W drugi weekend maja, jak to już ma miejsce w długoletniej tradycji Zachodniego Uniwersytetu Michigan, USA, odbył się po raz LIV Międzynarodowy Kongres Studiów Mediewistycznych w Kalamazoo, gdzie swoją siedzibę ma Uniwersytet. Cały Kongres jest organizowany przez Instytut Mediewistyczny. Kontynuuje się tu wyrobioną praktykę organizacyjną, która rozpoczyna się we wrześniu poprzedniego roku zbieraniem propozycji wykładów (i wystaw), które następnie szereguje się i łączy w kilka bloków tematycznych. Tak powstają sesje (jedna rano, dwie po południu), każda zawierająca od 3 do 4 wykładów tematycznych. Wykład powinien trwać góra $20 \mathrm{~min}$, a po nim jest czas na 10-minutową dyskusję. Każdą sesję prowadzi osoba zaznajomiona w tematyce. Tematyka, jak zawsze, jest przeróżna, obejmuje całe bogactwo życia w średniowieczu, włącznie z życiem intymnym, seksualnym, zboczeniami itp. Pod koniec całego procesu tworzenia Kongresu powstaje specjalna pozycja książkowa zbierająca owoce prac różnych komisji, które dokonują selekcji i kompila- 
cji materiału, składając go w jedną organizacyjną całość w celu wdrożenia go później w życie Kongresu. Powstała książka, oprócz ogłoszeń komercyjnych dotyczących wydania nowych pozycji z zakresu średniowiecza przez różne wydawnictwa ze świata, informuje każdego uczestnika Kongresu o miejscu i tytule każdej sesji, sposobie rejestracji, możliwości zjedzenia posiłków i zakwaterowania, a także daje ogólne wskazówki, jak się poruszać po kampusie uniwersytetu.

W tym roku przewidziano 551 sesji rozrzucanych po wielu budynkach kampusu uniwersyteckiego. Jak co roku Kongres prezentuje dwie gościnne prelekcje w piątek i sobotę. W pierwszym przypadku był wykład Biserra V. Pentcheva pt. „Ikony Brzmienia i Liturgiczny Exultet Włoch Południowych” (Icons of Sound and the Exultet Liturgy of Southern Italy) sponsorowany przez Amerykańską Akademię Mediewistyczną. W drugim przypadku było wystąpienie Bonnie Wheeler pt. „Trwały Chaucer” (Enduring Chaucer) sponsorowany przez Wydawnictwo Uniwersytetu w Pensylwanii.

$\mathrm{Z}$ punktu widzenia autora dokonującego tego sprawozdania warty podkreślenia jest blok dziesięciu Konferencji Studiów Cysterskich i Monastycznych organizowanych przez Instytut Studiów Cysterskich w ramach Kongresu Mediewistycznego. I on szczególnie będzie przedmiotem dalszych rozważań.

W czwartek, 9 maja miały miejsce trzy sesje. Poranna sesja zatytułowana „Życie Monastyczne: Ideały i cnoty” (Monastic Life: Ideals and Virtues) była poświęcona ideałom i cnotom pielęgnowanym w teologii i środowisku cysterskim na podstawie pism Williama de St. Thierry, Guerica de Igny i Bernarda z Clairvaux. Dwie popołudniowe sesje dotyczyły po kolei studiów nad Aelredem z Rievaulx i Bernardem z Clairvaux (tu miał swoje wystąpienie autor niniejszego sprawozdania, „Aelred jako hagiografer”) oraz prezentacji dorobku naukowego znanego naukowca cysterskiego, przeora Klasztoru St. Mary w New Ringgold w Pensylwani, Luke Andersona. W tym ostatnim przypadku był to honorowy panel na czesć prof. Luke Andersona prowadzony przez prof. emerytowaną Uniwersytetu w Ohio, Marsha L. Dutton.

W piątek, 10 maja miały miejsce tylko dwie sesje. Przedpołudniowa sesja odzwierciedlała tematy kryjące się pod wspólnym tytułem „Cysterskie reformy i sukces w okresie średniowiecza i wczesnego modernizmu, w aspekcie prawnym i ekonomicznym" (Medieval and Early Cistercian Reform and Success: Legal and Economic Aspects). Popołudniowa sesja dotyczyła sposobu ekspresji dramatycznej przez Aelreda z Rievaulx (Aelred of Rievaulx and the Dramatic).

W sobotę, 11 maja znów miały miejsce trzy sesje. Pierwsza poświęcona była utworowi Bernarda z Claurvaux De consideratione i jego wpływo- 
wi na późniejszą twórczość franciszkańską i Dantego Alighieri (Bernard's De consideratione and Its Afterlife). Druga dotyczyła metafory kwiatowej w materialnej i duchowej kulturze monastycyzmu średniowiecznego (Floral Metaphors in the Material and Spiritual Culture of Medieval Monasticism). Ostatnia sesja tego dnia omawiała zagadnienie związane z z przepisywaniem tzw. exempla cysterskich, czyli spisywaniem (przepisywaniem, powielaniem) krótkich przykładów służących do duchowego zbudowania mnichów na przełomie XII i XIII wieku (Rewriting Cistercian Exempla between the End of the Twelfth and the Beginning og the Thirteenth Century).

Niedziela 12 maja była ostatnim dniem całego Kongresu, a w ramach Konferencji Studiów Cysterskich i Monastycznych zaplanowano i zrealizowano dwie przedpołudniowe sesje. Pierwsza była poświęcona ortodoksyjności, oryginalności i uniwersalności doktryny św. Gertrudy z Helfty (St. Gertrud the Great: Orthodoxy, Originality and Universality of Her Doctrine), druga - podobieństwom między teologią monastyczną i wczesnoscholastyczną (Monastic and Early Scholastic Theology: More Likeness than Difference?).

Jak zwykle Kongres Mediewistyczny w Kalamazoo zgromadził rzesze ludzi zafascynowanych różnoraką tematyką średniowieczną. Oprócz wielu naukowców parających się zawodowo średniowieczem można było zobaczyć wielu studentów i absolwentów uczelni głównie z USA, ale także i z całego świata, którzy chcieli poszerzyć i wymienić swoje kontakty naukowe i horyzonty myślowe. W ramach cysterskich studiów można było spotkać, usłyszeć i podyskutować z autorami książek poświęconych tematyce cysterskiej. Wystarczy wspomnieć takie postaci, jak: Luke Anderson, Marsha L. Dutton, Rozanne Elder, Martha Krieg, Daniel Marcel La Corte, Paul E. Lockey, Stefano Mula, Philip O’Mara, Jean Truax, itp.

Poza nielicznymi przypadkami z Uniwersytetu Warszawskiego (Jerzy Szafranowski), Polskiej Akademii Nauk (Paweł Figurski), niezależnych badaczy (Ewa Magdalena Charowska, Ryszard Groń) mało jest jeszcze polskich naukowców. Miejmy nadzieję, że nowe możliwości i formy dotacji z Unii Europejskiej będą ułatwiały wielu naszym rodakom uczestnictwo w podobnych Kongresach. Następny, LV Kongres w Kalamazoo już za rok, jak zwykle w drugim tygodniu (weekend) maja. Do 15 września należy składać propozycje wykładów na stronie Uniwersytetu Western Michigan. 